\title{
The relationship between Gender Inequality and Political and social integration
}

\author{
1Zinah Hasan Hussein \\ 1 Sociology Department, College of Art, University of Salahuddin, Erbil , Kurdistan Region of Iraq
}

\begin{abstract}
This study examines the relationship between gender inequality and political and social integration, a critical links exist between economic, social and political variables in the quest to reach out of the reasons behind gender inequality for all citizens. This study suggests that political and social integration may increase the gender inequality positively or negatively. To test the proposed claims we need scientific analysis to produce meaningful results and significance. And here we develop our research question which is: how does political and social integration effects gender inequality?

Quantative data which I use in this paper comes from The Quality of Government (QoG) based on the cross-sectional data. The results covers 194 countries, the conceptualization and operationalization used in study on the impact of gender inequality will be reviewed. And the theoretical framework usually used to study peace operations contributions in quantitative research will also be summarized. Moreover, the main findings using codebook capturing results of dependent and independent variables will be presented, including the results of control variables influences.
\end{abstract}

Keywords: Gender inequality, social integration, political integration, scatter plot, multi regression analysis.

\section{Introduction}

The relationship between gender inequality and political and social integration, not to forget how socioeconomic level or rule of law, has been in history which sets off from the beginning of our knowledge of state formation and function of state. Due to the recent developments in international political and economic spheres, the concept of political and social integration has gained much more attentions than ever before. Particularly the era beyond the second great war in forties that had brought about some dimensions to the integration of society politically, socially and economically. Political and Social integration is a highly desirable outcome that reflects the existence of sociopolitical cohesion, a strong institutional foundation and

Academic Journal of Nawroz University

(AJNU) Volume 9, No 1 (2020).

Regular research paper: Published 18 Feb 2020

Corresponding author's e-mail : zinah.hasan@gmail.com

Copyright @2018 Zinah Hasan Hussein.

This is an open access article distributed under the Creative

Commons Attribution License. a culture of acceptance. Societies are better off if they promote political and social integration through inclusive policies that reduce economic inequality and poverty, and promote sustainable and equitable development. ${ }^{i}$ Because of its qualitative nature, gender inequality can be measured by using variables that capture and measure how much political and social integration exists in a community at any given time (Haney-Lopez, 2000; Omi \& Winant, 1986). Identifying these indicators can be tricky and it may entail using quantitative and qualitative data. Many development practitioners and policy makers center attention on the creation of economic opportunities as the material basis for social integration. In this way, there is often a tendency to underscore economic goals and make them uniquely critical.

In developed countries, the goals of stable, productive and decent employment and poverty elimination have been firmly grounded in social contracts and have 
therefore influenced labor and welfare policies in meaningful ways (Almond \& Verba, 1963; Campbell, Converse, Miller, \& Stokes, 1960; McCluskey, Deshpande, Shah, \& McLeod, 2004; Verba et al., 1995). European social democracies have been engaged in attaining socio-economic goals that bring stability and social cohesion both within each individual nation and within the European Union. In contrast, the developing world has faced persistent obstacles in its efforts to attain these twin goals despite its recent economic expansion ${ }^{\text {ii }}$. While social integration is more viable when societies move toward sound economic goals, (Verba \& Nie, 1972; Verba, Nie, \& Kim, 1978). There are key non-economic elements that are part of building integrated and cohesive societies.

This study review critical links that exist between economic, social and political variables in the quest to reach out of the reasons behind gender inequality for all citizens. The goal of promoting political and social integration through actions that eliminate discrimination and other forms of intolerance and rejection is as important as the creation of economic opportunities. This study does not aim to provide complete answers to this relationship, seeking instead to review and contextualize the wealth of quantitative research method on this topic. Importantly, before appropriate answers are found, our independent and dependent variables must be defined. ${ }^{i i i}$ The dependent variable is the gender inequality and the independent variable is political and social integration, as well as using three control variables to stress out the relationship between the independent and dependent variables. Control variable used in this study are: rule of law, stability of democratic institutions and socioeconomic level. The paper's main results and conclusion are presented at the end.

\subsection{What is political and social integration?}

Political and Social integration is the process of creating unity, integration and participation at all levels of society within the diversity of personal attributes so that every person is free to be the person she wants to be. Personal attributes include socio-economic class, age, gender sexual preference and expression, political ideas, ethnicity and cultural traits, religion, citizenship (national origin) and geographical region of origin and so on. Krieger (1999) political and social integration enables persons, regardless of their attributes, to enjoy equal opportunities, rights and services that are available to the so-called mainstream group. (Kinder \& Sears, 1981) Social integration can be considered to be antonym to social exclusion, which is broader than poverty and deprivation, and which neglects people's rights. ${ }^{\text {iv }}$

Political and Social exclusion is produced by systematic and institutional discrimination, gender inequality or other forms of rejection that leave out persons or groups from the mainstream system of economic, social, and political relationships (Dahl, 1961). Access to these relationships enables the privileged to be active participants in society benefiting from cultural, economic, social and political exchanges. Excluded persons and groups do not partake in the benefits of social capital with identical sense of belonging (Campbell, 2003; Marcus, Neuman, \& McKuen, 2000; Miller \& Krosnick, 2004). And in worse situations, the intensity of rejection and intolerance can create emotional and physical harm to excluded persons. To protect themselves, victims of discrimination and intolerance form smaller and tightly connected networks of solidarity and support among themselves and their allies in safe places.

\subsection{What is gender inequality?}

"Men and women are not equal and that gender affects an individual's lived experience. These differences arise from 
distinctions in biology, psychology, and cultural norms. Some of these distinctions are empirically grounded while others appear to be socially constructed. Studies show the different lived experience of genders across many domains including education, life expectancy, personality, interests, family life, careers, and political affiliations. Gender inequality is experienced differently across cultures" v (Dawson, 1994; Matthews \& Prothro, 1966; McAdam, 1982; Parker, 2009).

This paper measure and study the relationship between gender inequality in the many countries that have not had problems with political and social integration. To provide a more nuanced depiction of how gender inequality impacted by political and social integration, the following study will also define the impact of the rule of law, stability of democratic institutions and socio-economic level on the gender inequality. Combining these control variables will shed clear light on the relationship between gender inequality and political and social integration. While this study suggests that political and social integration may increase the gender inequality positively or negatively. To test the proposed claims we need scientific analysis to produce meaningful results and significance. And here we develop our research question which is: how does political and social integration effects gender inequality?

\section{Theoretical framework}

Study of gender inequality has received extensive attention by socio-political scientists. Several major theories have been developed to explain why some individuals engage in politics and social life whereas others do not. The conventional view is that political and social activities is a function of at least three factors: individual level resources, recruitment, and psychological orientations. For instance, based on Verba, Schlozman, and Brady's (1995) civic voluntarism model, Rosenstone and Hansen's (1993) account of political mobilization and participation, and standard socioeconomic status models (Verba \& Nie, 1972; Verba, Nie, \& Kim, 1978), we know that older citizens of higher socioeconomic strata and those who are asked to take part in politics participate more. While these theories explain who is most likely to participate, they do not, however, sufficiently explain why and under what circumstances individuals are likely to spend their time, skills, and resources on the political process. For most people, political activity seems rather remote considering the many responsibilities and distractions of everyday life (Dahl, 1961). Despite having an abundance of resources, some individuals may not take interest in politics (Gamson, 1968). Hence, scholars have determined that in addition to attitudinal determinants of political activism - such as strength of party attachment, amount of political trust, interest, and efficacy, and the strength of people's issue attitudes (Almond \& Verba, 1963; Campbell, Converse, Miller, \& Stokes, 1960; McCluskey, Deshpande, Shah, \& McLeod, 2004; Verba et al., 1995)-political context plays a critical role in understanding psychological motivations behind political involvement. Specifically, a key impetus for political mobilization is the awareness of undesirable political conditions or political threat. Research demonstrates that individuals are especially likely to take action when posed with a direct or indirect threat

Understanding the phenomenon of gender inequality and standing at its causes and understanding of the relations between different factors may lead to the treatment of this phenomenon in the appropriate ways, which brings equity to the state and thus provide a clear motive for all gender to participate. ${ }^{\mathrm{vi}}$ Here the importance of the question of the nature of the relationship between gender inequality and political 
and social integration. And test our hypotheses which is:

Null hypotheses: there is no correlation between gender inequality and political and social integration. Alternative hypotheses: there is correlation between gender inequality and political and social integration.

While these theoretical mechanisms imply reasonable expectations on the impact of political and social integration on gender inequality, their empirical testing presents several challenges. First, data collection on gender inequality has lagged behind an increasing interest in disaggregating the analytical unit, in time and space. vii The first quantitative wave (Diehl, 1988; Doyle \& Sambanis, 2000; Fortna, 2008) focused mostly on country-years or conflict spells. Only with the second wave has the empirical study of gender inequality started moving to temporal (monthly) and spatial (subnational) disaggregation (Costalli, 2014; Di Salvatore, 2017; Hultman, Kathman, \& Shannon, 2013, 2014; Ruggeri, Gizelis, \& Dorussen, 2012; Ruggeri, Dorussen, \& Gizelis, 2016a, 2016b). Moreover, new data on different dimensions of gender inequality are now available, such as personnel contribution to states (Kathman, 2013), gender composition (Karim \& Beardsley, 2016), gender inequality (Bove, Ruggeri, \& Zwetsloot, 2017), and georeferenced event data (Dorussen \& Ruggeri, 2017). 4

A second challenge is causal identification. Gender inequality is not random, which creates problems when estimating the treatment effect. The evolution of empirical approaches has substantially increased our confidence in the evidence supporting political stability. Over time, the literature has introduced new and more nuanced measurements of gender inequality as explanatory variables for being stable. These range from unfair, immoral, and illegitimate government practices ( Diehl, 1988 ) ( Doyle \& Sambanis, 2000;
Fortna, 2008 ), to shared racial identity ( Hultman et al., 2013, 2014; Bove \& Ruggeri, 2015 ) and, more recently, historical and contemporary experiences of unequal treatment ( Costalli, 2014; Ruggeri, Dorussen, \& Gizelis, 2016b ).

Gender inequality has primarily been the focus of social psychologists. This is evidenced by a growing body of quantitative population-based studies of various racial and ethnic groups, which have drawn a direct link between social exclusion and mental health impairments (see Mays, Cochran, \& Barnes, 2007; Paradies, 2006; Pascoe \& Richman, 2009; Williams \& Mohammed, 2009). Overall, the common theme that emerges from these studies raises an important question for the study of gender inequality and political and social integration.

\section{Methodology}

Quantative data which I use in this paper comes from The Quality of Government (QoG) based on the crosssectional data. "Institute that is founded in 2004. It is an independent research institute within the Department of Political Science at the University of Gothenburg. The institute conducts research on the causes, consequences and nature of Good Governance and the Quality of Government (QoG) - that is, trustworthy, reliable, impartial, uncorrupted, and competent government institutions. The QoG Standard dataset consists of 2100 variables from more than 100 data sources. The results covers 194 countries." (QOG Standard Dataset 2018 Codebook)

The conceptualization and operationalization used in study on the impact of gender inequality will be reviewed. And the theoretical framework usually used to study peace operations contributions in quantitative research will also be summarized. Moreover, the main findings using codebook capturing results of dependent and independent variables will be presented, including 
the results of control variables influences. Quantitative work on gender inequality is available, and qualitative scholars have provided substantial and critical contributions to understanding the impact political stability on peace operations contributions viii. However, the study of gender inequality will look into all available stats all over the world.

Gender inequality remains a major barrier to human development. Girls and women have made major strides since 1990, but they have not yet gained gender equity. The disadvantages facing women and girls are a major source of inequality. All too often, women and girls are discriminated against in health, education, political representation, labour market, etc.-with negative consequences for development of their capabilities and their freedom of choice.

"The GII is an inequality index. It measures gender inequalities in three important aspects of human development-reproductive health, measured by maternal mortality ratio and adolescent birth rates; empowerment, measured by proportion of parliamentary seats occupied by females and proportion of adult females and males aged 25 years and older with at least some secondary education; and economic status, expressed as labour market participation and measured by labour force participation rate of female and male populations aged 15 years and older. The GII is built on the same framework as the IHDI - to better expose differences in the distribution of achievements between women and men. It measures the human development costs of gender inequality. Thus the higher the GII value the more disparities between females and males and the more loss to human development."

The GII sheds new light on the position of women in 160 countries; it yields insights in gender gaps in major areas of human development. The component indicators highlight areas in need of critical policy intervention and it stimulates proactive thinking and public policy to overcome systematic disadvantages of women.

The GII is an inequality index. It shows the loss in potential human development due to disparity between female and male achievements in three dimensions, reproductive health, empowerment and economic status. Overall, the GII reflects how women are disadvantaged in these dimensions. The GII ranges between 0 and 1. Higher GII values indicate higher inequalities and thus higher loss to human development. There is no country with perfect gender equality. All countries suffer some loss in achievements in key aspects of human development when gender inequality is taken into account. The GII is similar in method to the Inequality-adjusted Human Development Index (IHDI) - see Technical Note 4 for details. It can be interpreted as a combined loss to achievements in reproductive health, empowerment and labour market participation due to gender inequalities. Since the GII includes different dimensions than the HDI, it cannot be interpreted as a loss in HDI itself.

The cases for this study are 160 from 196 countries of the QOG standard dataset 2019 (CODE BOOK). These countries represent a population within the field of study. Whilst this means that they are technically not a sample it will still be useful to treat them as a sample of the wider world throughout time. Hopefully this will mean that we can say with greater confidence that the results we will found are valid to generalize as well as having current time-period empirical validity.

The observations in the scatter plot are countries. Gender inequality and political social integration are variables that have effects on a country. The independent variable is political and social integration while dependent variable is gender inequality. Therefore, both of these variables will be analyzed 
using the empirical data provided. The unit of analysis also known as observations are countries around the world.

Political and social integration is measured by data provided by "Bertelsmann Transformation Index The Bertelsmann Stiftung's Transformation Index (BTI)" is a tool that measures and evaluates the quality of democracy, a market economy and political management in 129 developing and transition countries. Stable patterns of representation exist for mediating between society and the state; there is also a consolidated civic culture 1-10.

Pearson's correlation will be used to define the positive or negative relationship between the variables. Nevertheless, with the variables analysed we will clearly obtain the results. The research will be shown in scatter plots and correlations to understand the relationship between the variables.

For the confirmation of the influence of gender inequality on political and social integration, other independent variables will be examined in order to come up with an empirical explanation. In the results, the independent variable is 'Rule of Law': "State powers check and balance one another and ensure civil rights. Including "To what extent is there a working separation of powers (checks and balances)?", "To what extent does an independent judiciary exist?", "To what extent are public officeholders who abuse their positions prosecuted or penalized?" and "To what extent are civil rights guaranteed and protected, and to what extent can citizens seek redress for violations of these rights?". Data collected using Bertelsmann Stiftung results as the data source.

Another variable is Stability of Democratic Institutions and it has been measured by Bertelsmann Transformation Index. "Democratic institutions are capable of performing, and they are adequately accepted 1-10. Let me first define what do I mean by the
Democratic institutions are capable of performing; Major functions of modern government include (1) foreign diplomacy, (2) military defence, maintenance of domestic order, (4) administration of justice, (5) protection of civil liberties, (6) provision for ad regulation of the conduct of periodic elections, (7) provision for public goods and services, (8) promotion of economic growth and development, (9) operation of social- insurance programs to prevent future poverty, and (10) operation of social-welfare programs to alleviate existing poverty. ${ }^{\mathrm{ix}}$

The next variable is Socio-Economic Level: In principle, the country's level of development permits adequate freedom of choice for all citizens 1-10. The socioeconomic performance is good. Moderately positive macroeconomic data may include low GDP growth rates, only moderate unemployment levels, relative price stability, a slightly unbalanced budget, a tendency toward debt and a manageable current account position. 10. The socio-economic performance is very good. Positive macroeconomic data may include relatively high GDP growth rates, relatively high employment levels, price stability, balanced budget, reasonable debt and a sustainable current account position. Socio-economic development are obviously mutual preconditions: gender inequality is a precondition for economic and social development as much as economic and social development is a precondition for political stability within the participating countries." (QOG Standard Dataset 2018 Code book). There is a positive association between the presence of gender inequality and socio-economic level. The regression analysis has been calculated using the dependent variable with the other independent variables to find out the relationship with national security. The importance of the linear regression is to calculate the value of the dependent variable amongst 
the independent variables.

To display values for typically two variables for a set of data, scatter plot is used. A scatter plot is a type of plot or mathematical diagram using Cartesian coordinates. The data are displayed as a collection of points, each having the value of one variable determining the position on the horizontal axis and the value of the other variable determining the position on the vertical axis. It is used to show the relationship between two variables to show how they are correlated. The Beta Coefficients are either positive or negative in the table. The Beta coefficient provides the degree of charge in the dependent variable for every one unit of charge in the independent variable. According to the linear regression if the Beta Coefficient is positive, every one unit charge in the independent variable will increase and the Beta Coefficient will increase the dependent variable. Provided that the Beta Coefficient is negative, then every one unit increase in the independent variable, the Beta Coefficient will decrease the dependent variable.

The R-Squared indicates the amount of variances gender inequality is explained by political social integration. In this paper I study how gender inequality effects the political and social integration.

\section{The Results}

The empirical data obtained by the variables gender inequality and political and social integration would be demonstrated in Table 1 which shows the correlation between the independent variable the dependent variable with 125 observations. The graphical observation is also introduced in figure 1.

Table 1. Correlation of the Dependent Variables (gender inequality) and Independent Variables (political and social integration)

\section{Correlations}

\begin{tabular}{|c|c|c|c|}
\hline & & $\begin{array}{l}\text { Gender } \\
\text { Inequality } \\
\text { Index }\end{array}$ & $\begin{array}{l}\text { Political } \\
\text { and } \\
\text { Social } \\
\text { Integrat } \\
\text { on }\end{array}$ \\
\hline \multirow{3}{*}{$\begin{array}{l}\text { Gender } \\
\text { Inequality } \\
\text { Index }\end{array}$} & $\begin{array}{l}\text { Pearson } \\
\text { Correlation }\end{array}$ & 1 & $.320^{* *}$ \\
\hline & Sig. (2-tailed) & & .000 \\
\hline & $\mathrm{N}$ & 186 & 125 \\
\hline \multirow{3}{*}{$\begin{array}{l}\text { Political and } \\
\text { Social } \\
\text { Integration }\end{array}$} & $\begin{array}{l}\text { Pearson } \\
\text { Correlation }\end{array}$ & $.320^{* *}$ & 1 \\
\hline & Sig. (2-tailed) & .000 & \\
\hline & $\mathrm{N}$ & 125 & 128 \\
\hline
\end{tabular}

The result of the Pearson correlation significance between the dependent and independent variable is positive (0.320) at (0.01) level of statistical significance, which means it has a strong relationship instead of an inverse relationship. This means that as one variable increases the other variable will increase as well. The pvalue is 0.00 less than .01 our confidence level then we reject the null hypothesis and accept the alternative hypothesis which is there is a significant correlation between gender inequality and political and social integration.

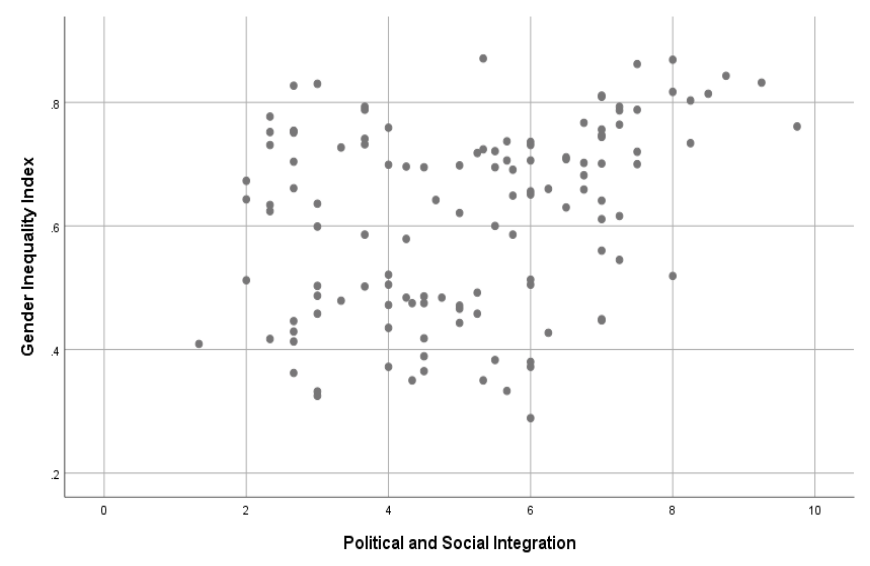

Figure 1. Scatter Plot for the correlation of the Dependent Variables (gender inequality) and Independent Variables (Political social integration)

The scatter plot graph also indicates that the relationship of the dependent variable and dependent 
variable has a strong movement. Therefore, the study proves the hypotheses political and social integration has an effect on gender inequality.

Table 2. Correlation of the Dependent Variables (gender inequality) and Independent Variables (rule of law)

\begin{tabular}{|l|l|l|l|}
\hline \multicolumn{2}{|l|}{ Correlations } \\
\hline \multicolumn{2}{|c|}{} & $\begin{array}{l}\text { Gender } \\
\text { Inequality } \\
\text { Index }\end{array}$ & $\begin{array}{l}\text { Rule of } \\
\text { Law }\end{array}$ \\
\hline \multirow{2}{*}{$\begin{array}{l}\text { Gender } \\
\text { Inequality } \\
\text { Index }\end{array}$} & Pearson Correlation & 1 & $.396^{* *}$ \\
\cline { 2 - 4 } & Sig. (2-tailed) & & .000 \\
\cline { 2 - 4 } & $\mathrm{N}$ & 186 & 125 \\
\hline \multirow{3}{*}{ Rule of Law } & Pearson Correlation & $.396^{* *}$ & 1 \\
\cline { 2 - 4 } & Sig. (2-tailed) & .000 & 128 \\
\cline { 2 - 4 } & $\mathrm{N}$ & 125 & 12 level (2-tailed). \\
\hline **. Correlation is significant at the 0.01 leved
\end{tabular}

\section{Significant Correlation}

Table 2: The p-value is 0.00 less than .01 our confidence level then we reject the null hypothesis and accept the alternative hypothesis which is there is a significant correlation between gender inequality and political and social integration. Pearson correlation: shows moderate-strong positive correlation between gender inequality and rule of law.

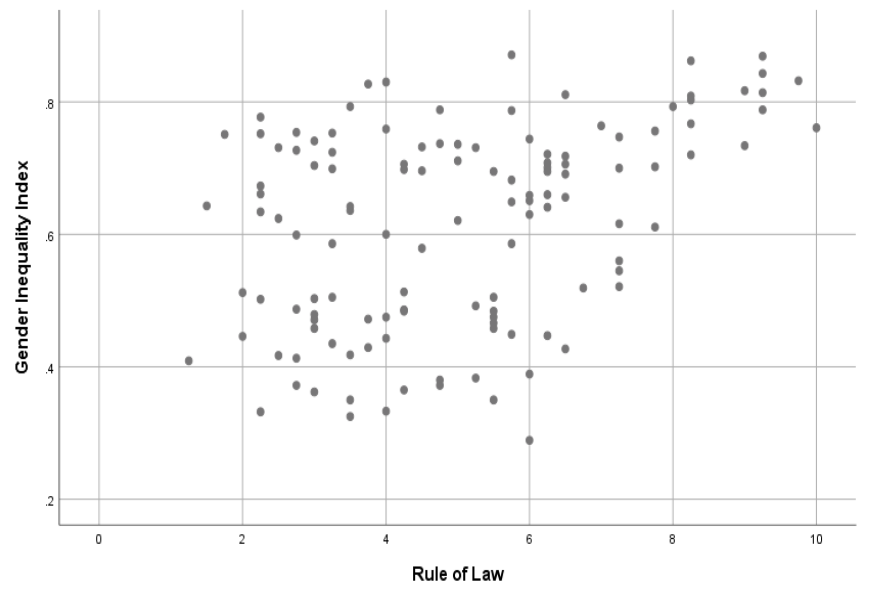

Figure 2. Scatter Plot for the correlation of the Dependent Variables (gender inequality) and Independent Variables (rule of law)

The observations on the scatter plot above show that the correlation being strong and positive demonstrates the direction of the trend line.

Table 3. Correlation of the Dependent Variables (gender inequality) and Independent Variables (stability of democratic institutions)

\begin{tabular}{|l|l|l|l|}
\hline \multicolumn{2}{|l|}{ Correlations } & $\begin{array}{l}\text { Gender } \\
\text { Inequality } \\
\text { Index }\end{array}$ & $\begin{array}{l}\text { Stability of } \\
\text { Democratic } \\
\text { Institutions }\end{array}$ \\
\hline \multirow{2}{|c|}{$\begin{array}{l}\text { Gender } \\
\text { Inequality } \\
\text { Index }\end{array}$} & Pearson Correlation & 1 & $.245^{* *}$ \\
\cline { 2 - 4 } & Sig. (2-tailed) & & .006 \\
\cline { 2 - 4 } & $\mathrm{N}$ & 186 & 125 \\
\hline $\begin{array}{l}\text { Stability of } \\
\text { Democrati } \\
\text { c } \\
\text { Institutions }\end{array}$ & Pearson Correlation & $.245^{* *}$ & 1 \\
\cline { 2 - 4 } & Sig. (2-tailed) & .006 & 128 \\
\cline { 2 - 4 } **. Correlation is significant at the 0.01 level (2-tailed). \\
\hline
\end{tabular}

Table 3 depicts the significance correlation between gender inequality and stability of democratic institutions with 186 observations. The result of the correlation between the dependent and independent variable is positive which means it has a direct relationship instead of a inverse relationship. This means that as one variable increases the other variable increases as well. The p-value is 0.006 our confidence level, we reject the null hypothesis and accept the alternative hypothesis which is there is a significant correlation between gender inequality and stability of democratic institutions.

Figure 3. Scatter Plot for the correlation of the Dependent

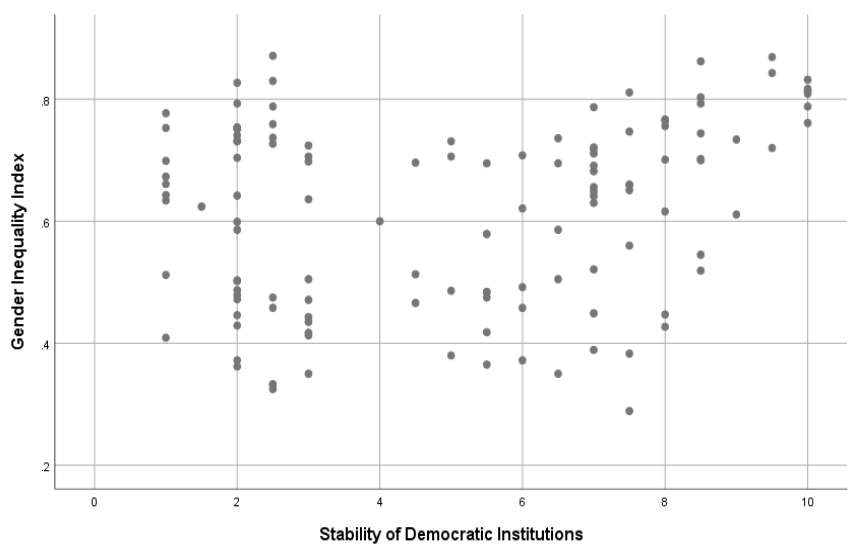

Variables (gender inequality) and Independent Variables (stability of democratic institutions) 
The observations on the scatter plot above show that the correlation being strong and positive demonstrates the direction of the trend line.

Table 4. Correlation of the Dependent Variables (gender inequality) and Independent Variables (socio-economic level)

\begin{tabular}{|l|l|l|l|}
\hline \multicolumn{2}{|l|}{ Correlations } & $\begin{array}{l}\text { Gender } \\
\text { Inequality } \\
\text { Index }\end{array}$ & $\begin{array}{l}\text { Socio- } \\
\text { Economic } \\
\text { Level }\end{array}$ \\
\hline \multirow{2}{|c|}{$\begin{array}{l}\text { Gender Inequality } \\
\text { Index }\end{array}$} & $\begin{array}{l}\text { Pearson } \\
\text { Correlation }\end{array}$ & 1 & $.890^{* *}$ \\
\cline { 2 - 4 } & Sig. (2-tailed) & & .000 \\
\cline { 2 - 4 } & $\mathrm{N}$ & 186 & 125 \\
\hline $\begin{array}{l}\text { Socio-Economic } \\
\text { Level }\end{array}$ & $\begin{array}{l}\text { Pearson } \\
\text { Correlation }\end{array}$ & $.890^{* *}$ & 1 \\
\cline { 2 - 4 } & Sig. (2-tailed) & .000 & 128 \\
\cline { 2 - 4 } & $\mathrm{N}$ & 125 & 125 \\
\hline **. Correlation is significant at the 0.01 level (2-tailed). \\
\hline \multicolumn{4}{|l|}{}
\end{tabular}

Table 4 the result of the Pearson correlation significance between the dependent and independent variable is positive (0.890) at (0.01) level of statistical significance, which means it has a strong relationship instead of an inverse relationship. This means that as one variable increases the other variable will increase as well. The pvalue is 0.00 less than .01 our confidence level then we reject the null hypothesis and accept the alternative hypothesis which is there is a significant correlation between gender inequality and political and social integration.

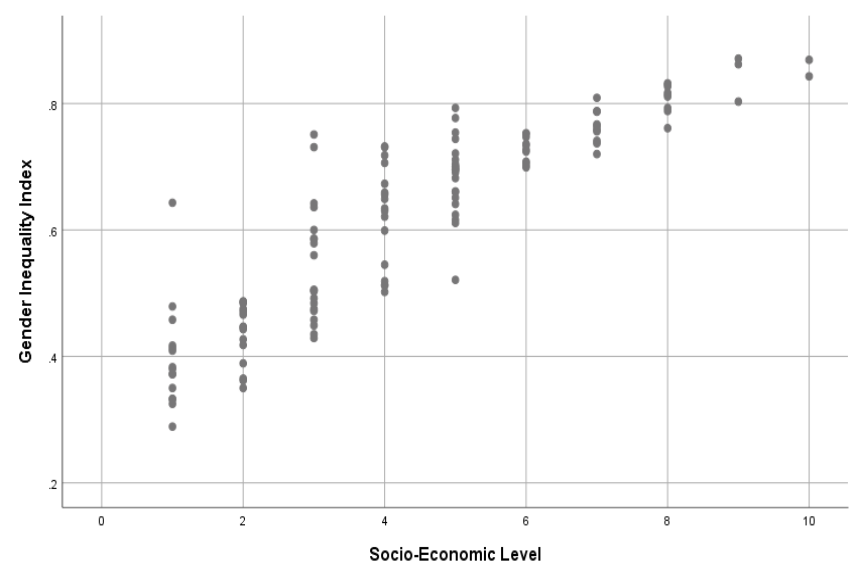

Figure 4. Scatter Plot for the correlation of the Dependent Variables (gender inequality) and Independent Variables (socio-economic level)

The observations on the scatter plot above show that the correlation being strong and positive demonstrates the direction of the trend line.

Table 5. The Regression between gender inequality and Political and social integration, rule of law, stability of democratic institutions and socio-economic level.

Number of Observations $=168$

\begin{tabular}{|l|l|l|l|}
\hline \multicolumn{1}{|c|}{ Gender inequality } & Coefficient & P - Value & R-Square \\
\hline $\begin{array}{l}\text { Political and social } \\
\text { integration }\end{array}$ & 0.557 & 0.000 & 0.102 \\
\hline Rule of Law & 0.534 & 0.000 & 0.157 \\
\hline $\begin{array}{l}\text { Stability of democratic } \\
\text { institutions }\end{array}$ & 0.493 & 0.006 & 0.060 \\
\hline Socio-economic level & 0.348 & 0.000 & 0.793 \\
\hline
\end{tabular}

The degree of causality between dependent and independent according to the analysis, the study has been able to show a causal relationship between $X$ and $\mathrm{Y}$ variables as demonstrated above (0.557). As a result, a positive relationship between internet and democracy occurs at (0.01) significant level. Thus, this the invariable means a 95\% correlation and confidence level between the independent and the dependent variable. In table 5, The R-Squared has indicated $10 \%$ the amount of variances gender inequality is explained by Political and social integration, stability of democratic institutions and rule of law, whereas socio-economic level is about $80 \%$ the amount of variances gender inequality explained.

The linear regression for the relationship between Political and social integration and gender inequality has been calculated by using the Beta Coefficient which is 0.557 . Due to its coefficient being positive, for each additional increase in gender inequality when we have increase in political and social integration will also 
increase by the coefficient. The P-value $(0.000)$ is less than 0.01 so the hypothesis will be rejected because of not having significance.

\section{Coefficients}

\begin{tabular}{|c|c|c|c|c|c|c|}
\hline \multirow{2}{*}{\multicolumn{2}{|c|}{ Model }} & \multicolumn{2}{|c|}{$\begin{array}{l}95.0 \% \\
\text { Confidence } \\
\text { Interval for B }\end{array}$} & \multicolumn{3}{|c|}{ Correlations } \\
\hline & & \multirow{2}{*}{$\begin{array}{l}\begin{array}{l}\text { Lower } \\
\text { Bound }\end{array} \\
.408 \\
\end{array}$} & \multirow{2}{*}{$\begin{array}{l}\text { Upper } \\
\text { Bound } \\
.557 \\
\end{array}$} & \multirow[t]{2}{*}{$\begin{array}{l}\text { Zero- } \\
\text { order }\end{array}$} & \multirow[t]{2}{*}{ Partial } & \multirow[t]{2}{*}{ Part } \\
\hline 1 & (Constant) & & & & & \\
\hline & $\begin{array}{l}\text { Political } \\
\text { and Social } \\
\text { Integration }\end{array}$ & .012 & .039 & .320 & .320 & .320 \\
\hline
\end{tabular}

a. Dependent Variable: Gender Inequality Index

Model Summary

\begin{tabular}{|c|c|c|c|}
\hline Model & $\mathrm{R}$ & R Square & $\begin{array}{ll}\text { Adjusted } & \mathrm{R} \\
\text { Square } & \end{array}$ \\
\hline 1 & $.320^{a}$ & .102 & .095 \\
\hline
\end{tabular}

a. Predictors: (Constant), Political and Social Integration

b. Dependent Variable: Gender Inequality Index

\section{ANOVAa}

\begin{tabular}{|lll|l|l|} 
Model & & Sum of Squares & df & Mea \\
\hline \multirow{2}{*}{1} & Regression & .295 & 1 & .295 \\
\cline { 2 - 5 } & Residual & 2.583 & 123 & .021 \\
\cline { 2 - 5 } & Total & 2.877 & 124 & \\
\hline
\end{tabular}

a. Dependent Variable: Gender Inequality Index

b. Predictors: (Constant), Political and Social Integration

The relationship between rule of law and gender inequality provides a Beta Coefficient of .534 which tells us that rule of law is positive and mean that when it increases by one unit, the gender inequality will decrease by coefficient as well. We are $95 \%$ confident of this correlation. On the other hand, the P-Value for rule of law is 0.000 which is less the level 0.01 . This means statistically significant to reject the Null hypothesis.

\section{Coefficientsa}

\begin{tabular}{|l|l|l|l|l|l|l|}
\hline \multicolumn{2}{|c|}{} & \multicolumn{2}{|l|}{$\begin{array}{l}\text { 95.0\% Confidence } \\
\text { Interval for B }\end{array}$} & \multicolumn{3}{|l|}{ Correlations } \\
\cline { 2 - 7 } & $\begin{array}{l}\text { Lower } \\
\text { Bound }\end{array}$ & $\begin{array}{l}\text { Upper } \\
\text { Bound }\end{array}$ & $\begin{array}{l}\text { Zero- } \\
\text { order }\end{array}$ & $\begin{array}{l}\text { Partia } \\
1\end{array}$ & Part \\
\hline \multirow{2}{*}{$\begin{array}{l}\text { Model } \\
\text { (Consta } \\
\text { nt) }\end{array}$} & .404 & .534 & & & \\
\cline { 2 - 7 } & $\begin{array}{l}\text { Rule of } \\
\text { Law }\end{array}$ & .017 & .041 & .396 & .396 & .396 \\
\hline
\end{tabular}

a. Dependent Variable: Gender Inequality Index
Model Summaryb

\begin{tabular}{|c|c|c|c|c|c|c|c|c|c|}
\hline \multirow[b]{2}{*}{$\begin{array}{l}\mathrm{M} \\
\mathrm{o} \\
\mathrm{d} \\
\mathrm{el}\end{array}$} & \multirow[b]{2}{*}{$\mathrm{R}$} & \multirow[b]{2}{*}{$\begin{array}{l}\mathrm{R} \\
\text { Squ } \\
\text { are }\end{array}$} & \multirow[b]{2}{*}{$\begin{array}{l}\text { Adju } \\
\text { sted } \\
\mathrm{R} \\
\text { Squa } \\
\text { re }\end{array}$} & \multirow[b]{2}{*}{$\begin{array}{l}\text { Std. } \\
\text { Error } \\
\text { of the } \\
\text { Estim } \\
\text { ate }\end{array}$} & \multicolumn{5}{|c|}{ Change Statistics } \\
\hline & & & & & $\begin{array}{l}\text { R } \\
\text { Squa } \\
\text { re } \\
\text { Chan } \\
\text { ge }\end{array}$ & $\begin{array}{l}\mathrm{F} \\
\mathrm{Ch} \\
\text { ang } \\
\mathrm{e}\end{array}$ & df1 & df2 & $\begin{array}{l}\text { Sig. F } \\
\text { Chan } \\
\text { ge }\end{array}$ \\
\hline 1 & $\begin{array}{l}.39 \\
6^{a}\end{array}$ & $\begin{array}{l}.15 \\
7\end{array}$ & .150 & .140 & .157 & $\begin{array}{l}22.8 \\
73\end{array}$ & 1 & 123 & .000 \\
\hline
\end{tabular}

a. Predictors: (Constant), Rule of Law

b. Dependent Variable: Gender Inequality Index

\section{ANOVA $^{\mathrm{a}}$}

\begin{tabular}{|l|l|l|l|l|l|l|}
\hline \multicolumn{2}{|l|}{ Model } & $\begin{array}{l}\text { Sum of } \\
\text { Squares }\end{array}$ & df & $\begin{array}{l}\text { Mean } \\
\text { Square }\end{array}$ & F & Sig. \\
\hline 1 & $\begin{array}{l}\text { Regres } \\
\text { sion }\end{array}$ & .451 & 1 & .451 & 22.87 & $.000^{\mathrm{b}}$ \\
\cline { 2 - 7 } & $\begin{array}{l}\text { Residu } \\
\text { al }\end{array}$ & 2.426 & 123 & .020 & 3 & \\
\cline { 2 - 7 } & Total & 2.877 & 124 & & & \\
\hline
\end{tabular}

a. Dependent Variable: Gender Inequality Index

b. Predictors: (Constant), Rule of Law

The Beta Coefficient between stability of democratic institutions and gender inequality is .602 this means when the independent variable extent and effect of stability of democratic institutions increases than the dependent variable gender inequality will increase. We are also $95 \%$ confident of this correlation. The P-Value for stability of democratic institutions is 0.006 which is lower than the alpha p-value 0.05 . The result we obtain from the value is statistically significantly.

\section{Coefficients ${ }^{\mathrm{a}}$}

\begin{tabular}{|c|c|c|c|c|c|}
\hline \multirow[b]{2}{*}{ Model } & \multicolumn{2}{|c|}{$\begin{array}{l}95.0 \% \\
\text { Confidence } \\
\text { Interval for B }\end{array}$} & \multicolumn{3}{|c|}{ Correlations } \\
\hline & $\begin{array}{l}\text { Lower } \\
\text { Bound }\end{array}$ & $\begin{array}{l}\text { Upper } \\
\text { Bound }\end{array}$ & $\begin{array}{l}\text { Zero- } \\
\text { order }\end{array}$ & $\begin{array}{l}\text { Part } \\
\text { ial }\end{array}$ & Part \\
\hline
\end{tabular}




\begin{tabular}{|l|l|l|l|l|l|l|}
\hline 1 & (Constant) & .493 & .602 & & & \\
\cline { 2 - 7 } & $\begin{array}{l}\text { Stability of } \\
\text { Democratic } \\
\text { Institutions }\end{array}$ & .004 & .023 & .245 & .245 & .245 \\
\hline
\end{tabular}

a. Dependent Variable: Gender Inequality Index

\section{Model Summaryb}

\begin{tabular}{|c|c|c|c|c|c|c|c|c|}
\hline \multirow{2}{*}{$\begin{array}{l}\text { Mo } \\
\text { del }\end{array}$} & \multirow[t]{2}{*}{$\mathrm{R}$} & \multirow{2}{*}{$\begin{array}{l}\text { R } \\
\text { Sq } \\
\text { ua } \\
\text { re }\end{array}$} & \multirow{2}{*}{$\begin{array}{l}\text { Adjusted } \\
\text { R Square }\end{array}$} & \multirow{2}{*}{$\begin{array}{l}\text { Std. } \\
\text { Error of } \\
\text { the } \\
\text { Estimat } \\
\text { e }\end{array}$} & \multicolumn{4}{|c|}{ Change Statistics } \\
\hline & & & & & \begin{tabular}{|l}
$\mathrm{R}$ \\
Square \\
Change
\end{tabular} & $\begin{array}{l}\text { F } \\
\text { Cha } \\
\text { nge }\end{array}$ & df2 & $\begin{array}{l}\text { Sig. F } \\
\text { Chan } \\
\text { ge }\end{array}$ \\
\hline 1 & $.245^{\mathrm{a}}$ & $\begin{array}{l}.06 \\
0\end{array}$ & .053 & .148 & .060 & $\begin{array}{l}7.87 \\
1\end{array}$ & 123 & .006 \\
\hline
\end{tabular}

a. Predictors: (Constant), Stability of Democratic Institutions

b. Dependent Variable: Gender Inequality Index

ANOVAa

\begin{tabular}{|l|l|l|l|l|l|l|}
\hline \multicolumn{2}{|l|}{ Model } & $\begin{array}{l}\text { Sum of } \\
\text { Square } \\
\text { s }\end{array}$ & $\begin{array}{l}\text { Mean } \\
\text { Square }\end{array}$ & F & Sig. \\
\hline 1 & $\begin{array}{l}\text { Regressi } \\
\text { on }\end{array}$ & .173 & 1 & .173 & 7.871 & $.006^{\mathrm{b}}$ \\
\cline { 2 - 7 } & Residual & 2.704 & 123 & .022 & & \\
\cline { 2 - 7 } & Total & 2.877 & 124 & & & \\
\hline
\end{tabular}

a. Dependent Variable: Gender Inequality Index

b. Predictors: (Constant), Stability of Democratic Institutions

Socio-Economic level and gender inequality have a Beta Coefficient relationship of .384 between them. In this case the Beta is positive and when Socio-economic level increase by one unit, gender inequality will increase as well accordingly by the coefficient. Confidence of this correlation is $95 \%$. The P-value for inflation is 0.000 which is less than the significance level 0.01. This means is not statistically significant to lead on the hypothesis.

\section{Coefficients $^{a}$}

\begin{tabular}{|l|l|l|l|l|l|l|}
\hline \multicolumn{2}{|c|}{} & \multicolumn{3}{l|}{$\begin{array}{l}95.0 \% \\
\text { Confidence } \\
\text { Interval for B }\end{array}$} & \multicolumn{3}{|l|}{ Correlations } \\
\cline { 2 - 7 } \multicolumn{2}{|c|}{} & $\begin{array}{l}\text { Lower } \\
\text { Bound }\end{array}$ & $\begin{array}{l}\text { Upper } \\
\text { Bound }\end{array}$ & $\begin{array}{l}\text { Zero- } \\
\text { order }\end{array}$ & $\begin{array}{l}\text { Part } \\
\text { ial }\end{array}$ & Part \\
\hline 1 & (Constant) & .330 & .384 & & & \\
\cline { 2 - 7 } & $\begin{array}{l}\text { Socio- } \\
\text { Economic } \\
\text { Level }\end{array}$ & .054 & .065 & .890 & .890 & .890 \\
\hline
\end{tabular}

a. Dependent Variable: Gender Inequality Index

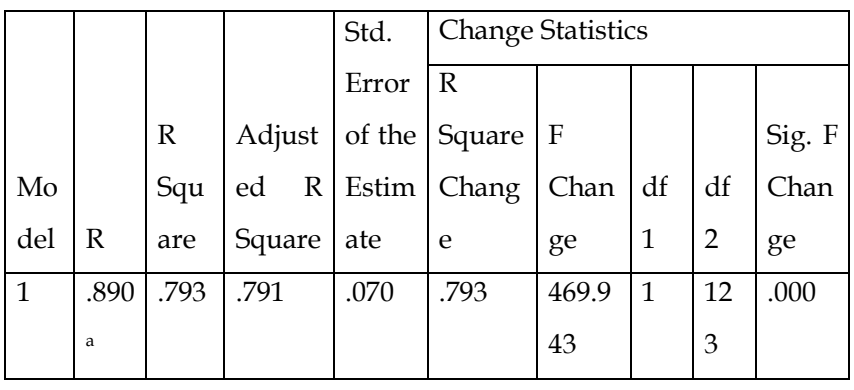

ANOVA $^{a}$

\begin{tabular}{|c|c|c|c|c|c|c|}
\hline \multicolumn{2}{|c|}{ Model } & $\begin{array}{l}\text { Sum } \\
\text { of } \\
\text { Squa } \\
\text { res }\end{array}$ & $\mathrm{df}$ & $\begin{array}{l}\text { Mean } \\
\text { Square }\end{array}$ & $\mathrm{F}$ & Sig. \\
\hline \multirow[t]{3}{*}{1} & $\begin{array}{l}\text { Regres } \\
\text { sion }\end{array}$ & 2.280 & 1 & 2.280 & $\begin{array}{l}469.9 \\
43\end{array}$ & $\begin{array}{l}.000 \\
\mathrm{~b}\end{array}$ \\
\hline & $\begin{array}{l}\text { Residu } \\
\text { al }\end{array}$ & .597 & 123 & .005 & & \\
\hline & Total & 2.877 & 124 & & & \\
\hline
\end{tabular}

a. Dependent Variable: Gender Inequality Index

b. Predictors: (Constant), Socio-Economic Level

\section{Conclusion}

This paper provides an empirical investigation into the impact of gender inequality on political and social integration within the selected sample by data extracted from dataset (CODEBOOK 2019) We evaluate the political and social integration on whether countries 
were having gender inequality; by confirming the impact and the relationship analysing the rule of law, stability of democratic institutions, and socio-economic level as well. I argue that gender inequality has robust positive effects on political and social integration for any country, particularly third world countries. As for the relationship between gender inequality and political and social integration, there is a significant evidence to suggest that whenever we do not have comprehensive political and social integration, considerable rule of law, good level of stability in the democratic institutions and firm socio-economic level, gender inequality will be severely impacted. Data a studies that this study have used or consulted, exhibited a strong association between gender inequality and lack or not constant for our independent variables used in this study. Nevertheless, Outside of this study, measures of gender inequality are either too vague or have been ignored all together, necessitating further investigation into how political and socio economic factors in particular impacts the gender inequality. Because gender inequality is extremely hurtful, we should expect to see an end to socio-political exclusion.

The linear regression for the relationship between gender inequality and political and social integration has been calculated by using the Beta Coefficient which is 1.62. Due to its coefficient being positive, for each additional increase in political and social integration, gender inequality will also increase by the coefficient. The P-value (0.571) is higher than 0.05 so the hypothesis will be rejected because of having no significance. Finally, endogeneity could be explained as political and social integration effects gender inequality though gender inequality has the possibility to effect political and social integration.

\section{References}

1. Edgell, P., Gerteis, J., \& Hartmann, D. (2006). Atheists as "other": Moral boundaries and cultural membership in American Society. American Sociological Review, 71(2), 211-234. Esposito, J. L. (1999). The Islamic threat: Myth or reality? New York, NY: Oxford University Press. Essed, P. (1991). Understanding everyday racism: An interdisciplinary theory. Newbury Park, CA: Sage. Finch, B. K., Kolody, B., \& Vega, W. A. (2000). Perceived discrimination and depression among Mexican-origin adults in California. Journal of Health and Social Behavior, 41(3), 295-313.

2. Gamson, W. A. (1968). Power and discontent. Homewood, IL: Dorsey Press. Garcia, J. A. (2003). Latino politics in America: Community, culture, and interests.

3. Guthrie, B. J., Young, A. M., Williams, D. R., Boyd, C. J., \& Kintner, E. K. (2002). African American girls' smoking habits and day-to-day experiences with racial discrimination. Nursing Research, 51, 183-190.

4. Haney-Lopez, I. (2000). The social construction of race. In R. Delgado \& J. Stefancic (Eds.), Critical race theory: The cutting edge (pp. 141-151). Philadelphia, PA: Temple University Press. Harris, F. (1994). Something within: Religion as a mobilizer of African American political activism. Journal of Politics, 1, 42-68.

5. Howell, S., \& Shryock, A. (2003). Cracking down on diaspora: Arab Detroit and America's war on terror. Anthropological Quarterly, 76(3), 443-462.

6. Jalalzai, F. (2009). The politics of Muslims in America. Politics and Religion, 2(02), 163-199.Bottom of Form Jamal, A. (2005). The political participation and engagement of Muslim Americans: Mosque involvement and group consciousness. American Politics Research, 33, 521-544.

7. Jost, J. T. (1995). Negative illusions: Conceptual clarification and psychological evidence concerning false consciousness. Political Psychology, 16(2), 397-424.

8. Kim, J. (1999). The racial triangulation of Asian Americans. Politics \& Society, 27(1), 1-34. Kinder, D. R., \& Sears, D. O. (1981). Prejudice and politics: Symbolic racism versus racial threats to the good life. Journal of Personality and Social Psychology, 40(3), 414-431.

9. Krieger N. (1999). Embodying inequality: A review of concepts, measures, and methods for studying health consequences of discrimination. International Journal of 
Health Services: Planning, Administration, Evaluation, 29(2), 295-352.

10. Lanham, MD: Rowman \& Littlefield. Gibbons F. X., Gerrard, M., Cleveland, M. J., Wills, T. A., \& Brody, G. (2004). Perceived discrimination and substance use in African American parents and their children: A panel study. Journal of Personality and Social Psychology, 86(4), 517-529. Greenwald, G. (2012). NYPD spying program aimed at Muslims. Salon Politics News. Retrieved from http://www.salon.

com/2012/02/22/nypd_spying_program_aimed_at_mus lims/ Guterbock, T. M., \& London, B. (1983). Race, political orientation, and participation: An empirical test of four competing theories. American Sociological Review, 48(4), 439-453.

11. Leary, M. R., Terdal, S. K., Tambor, E. S., \& Downs, D. L. (1995). Self-esteem as an interpersonal monitor: The sociometer hypothesis. Journal of Personality \& Social Psychology, 68(3), 518-530.

12. Leonard, K. I. (2003). Muslims in the United States: The state of research. New York, NY: Russell Sage.

13. Maciejewski, P. K., Prigerson, H. G., \& Mazure, C. M. (2000). Self-efficacy as a mediator between stressful life events and depressive symptoms. Differences based on history of prior depression. British Journal of Psychiatry: Journal of Mental Science, 176, 373-378. Marcus, G. E., Neuman, W. R., \& MacKuen, M. (2000). Affective intelligence and political judgment. Chicago, IL: University of Chicago Press.

14. Marx, G. T. (1967). Protest and prejudice: A study of belief in the black community. New York, NY: Harper \& Row.

15. Matthews, D. R., \& Prothro, J. (1966). Negroes and the new southern politics. New York, NY: Harcourt, Brace \& World. Mays, V. M., Cochran, S. D., \& Barnes, N. W. (2007). Race, race-based discrimination, and health outcomes among African Americans. Annual Review of Psychology, 58(1), 201-225.

16. McAdam, D. (1982). Political process and the development of Black insurgency, 1930-1970. Chicago, IL: University of Chicago Press.

17. McCluskey, M. R., Deshpande, S., Shah, D. V., \& McLeod, D. M. (2004). The efficacy gap and political participation:
When political influence fails to meet expectations. International Journal of Public Opinion Research, 16(4), 437-455.

18. McDaniel, E. L. (2008). Politics in the pews: The political mobilization of Black churches. Ann Arbor, MI: University of Michigan Press. Michelson, M. R. (2000). Political efficacy and electoral participation of Chicago Latinos. Social Science Quarterly, 81(1), 136-150.

\section{Footnote}

1. Guterbock, T. M., \& London, B. (1983). Race, political orientation, and participation: An empirical test of four competing theories. American Sociological Review, 48(4), 439-453.

2. Finch, B. K., Kolody, B., \& Vega, W. A. (2000). Perceived discrimination and depression among Mexican-origin adults in California. Journal of Health and Social Behavior, 41(3), 295-313.

3. Dion K. L., \& Earn, B. M. (1975). The phenomenology of being a target of prejudice. Journal of Personality and Social Psychology, 32(5), 944-950.

4. Haney-Lopez, I. (2000). The social construction of race. In R. Delgado \& J. Stefancic (Eds.), Critical race theory: The cutting edge (pp. 141-151). Philadelphia, PA: Temple University Press.

5. Campbell, A. L. (2003). Participatory reactions to policy threats: Senior citizens and the defense of Social Security and Medicare. Political Behavior, 25(1), 29-49.

6. Beber, B., Gilligan, M. J., Guardado, J., \& Karim, S. (2017). Integration and Gender inequality, Liberia. International Organization, 71(1), 1-30.

7. Beber, B., Gilligan, M. J., Guardado, J., \& Karim, S. (2017). Integration and Gender inequality, Liberia. International Organization, 71(1), 1-30.

8. Kinder, D. R., \& Sears, D. O. (1981). Prejudice and politics: Symbolic racism versus racial threats to the good life. Journal of Personality and Social Psychology, 40(3), 414-431.

9. Kinder, D. R., \& Sears, D. O. (1981). Prejudice and politics: Symbolic racism versus racial threats to the good life. Journal of Personality and Social Psychology, 40(3), 414-431. 